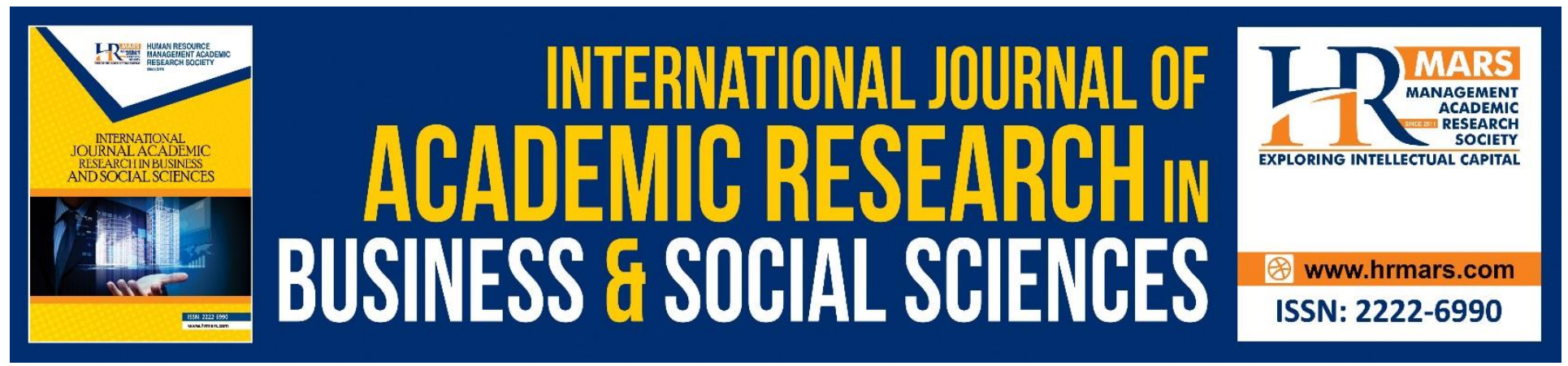

\title{
Factors Behind the Changes in Small Towns along the Selangor Northern Corridor Resulting from Spillover of The Klang-Langat Valley Metropolitan Region: A Confirmatory Factor Analysis Approach (CFA)
}

\author{
Y. Saleh, H. Mahat, M. Hashim, N. Nayan \& S.B. Norkhaidi
}

To Link this Article: http://dx.doi.org/10.6007/IJARBSS/v9-i2/5531

DOI: $\quad 10.6007 /$ IJARBSS/v9-i2/5531

Received: 07 Jan 2019, Revised: 24 Feb 2019, Accepted: 06 March 2019

Published Online: 07 March 2019

In-Text Citation: (Saleh, Mahat, Hashim, Nayan, \& Norkhaidi, 2019)

To Cite this Article: Saleh, Y., Mahat, H., Hashim, M., Nayan, N., \& Norkhaidi, S. B. (2019). Factors Behind the Changes in Small Towns along the Selangor Northern Corridor Resulting from Spillover of The Klang-Langat Valley Metropolitan Region: A Confirmatory Factor Analysis Approach (CFA). International Journal of Academic Research in Business and Social Sciences, 9(2), 159-174.

Copyright: (C) 2019 The Author(s)

Published by Human Resource Management Academic Research Society (www.hrmars.com)

This article is published under the Creative Commons Attribution (CC BY 4.0) license. Anyone may reproduce, distribute, translate and create derivative works of this article (for both commercial and non-commercial purposes), subject to full attribution to the original publication and authors. The full terms of this license may be seen at: http://creativecommons.org/licences/by/4.0/legalcode

Vol. 9, No. 2, 2019, Pg. 159 - 174

http://hrmars.com/index.php/pages/detail/IJARBSS

JOURNAL HOMEPAGE

Full Terms \& Conditions of access and use can be found at http://hrmars.com/index.php/pages/detail/publication-ethics 


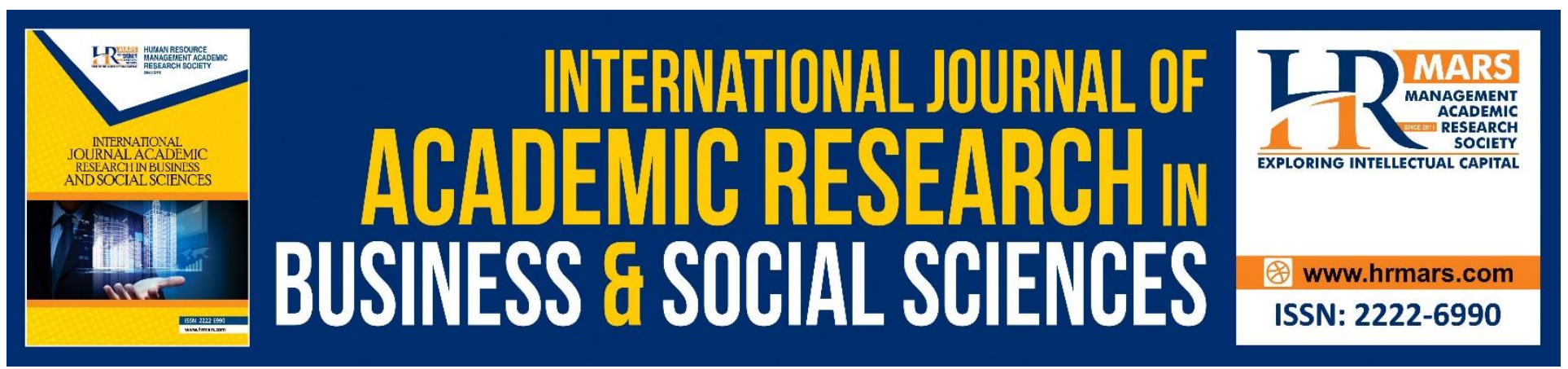

\title{
Factors Behind the Changes in Small Towns along the Selangor Northern Corridor Resulting from Spillover of The Klang-Langat Valley Metropolitan Region: A Confirmatory Factor Analysis Approach
} (CFA)

\author{
Y. Saleh, H. Mahat, M. Hashim, N. Nayan \& S.B Norkhaidi \\ Department of Geography \& Environment, Faculty of Human Sciences, \\ Sultan Idris Education University, 35900 Tanjong Malim, Perak, Malaysia. \\ Email: yazid@fsk.upsi.edu.my
}

\begin{abstract}
This article aims to verify the key factors behind the changes in small towns due to the spillover of the Klang-Langat Valley using Exploration Factor Analysis (EFA) and Confirmatory Factor Analysis (CFA) approaches. This study is based on the responses of 355 stakeholders from Hulu Selangor, Selangor, selected via random sampling. Likert scale questionnaires ranging from 1 to 5 were used to obtain feedback. Overall, the questionnaire was reliable with an Alpha Cronbach value for each construct greater than 0.7. The obtained data were processed through EFA in order to group the constructs and items for the change factor of small towns. The CFA was undertaken in order to verify the accumulated constructs based on their respective groups. The findings reveal the creation of six constructs: access (5 items), environment (5 items), security (2 items), activity (4 items), neighbourhood ( 2 items) and infrastructure ( 2 items). It is thus hoped that the findings of this research can help in identifying factors behind the transformation of small town due to the spillover of the Klang-Langat Valley. Indeed, the transformation is driving both positive and negative impacts on both urban and rural areas through socioeconomic development and ultimately contributing to improved quality of life in line with contemporary globalisation.

Keywords: Small Town, North Corridor Selangor State, Exploratory Factor Analysis (EFA), Confirmatory Factor Analysis (CFA), Klang Valley Langat Metropolitan Region
\end{abstract}




\section{INTRODUCTION}

Urbanisation is an expanding phenomenon around the world. It attracts the attention of urban geographers, planners and policymakers, because without proper planning and policy it may negatively affect the socioeconomic development of the population in a region or country. In line with globalisation flow, urbanisation is occurring at a rapid rate, especially in developing countries such as Malaysia, thereby increasing changes in urban growth patterns. Ironically, the rate of population growth in urban areas is higher and faster than the growth rate of the rural population: in the period 2000-2010, the average annual growth rate recorded was 2.17 percent in urban areas (Department of Statistics, Malaysia, 2014). This rate is directly contributing to the growth percentage rate of the major cities in Malaysia, especially the cities within the Klang Valley region such as Subang Jaya (5.1\%), Petaling Jaya (3.6\%), Shah Alam (3.5\%) and Klang (2.8\%) (Mohd Fadzil \& Ishak, 2014).

A further stimulus is globalisation, a process encouraging the relationship between urban and rural areas. According to Katiman (2014), globalisation has influenced the formation of urban spaces in developing countries. One such impact is the development of extended metropolitan regions (EMRs), which represents a process towards the formation of megacities. The spatial transformation process (and especially changes in land use, settlement functions and subsequently social change) is occurring at a very rapid rate. The core area starts to become crowded and eventually causes urbanisation to spread into peripheral areas. The suburbs of metropolitan areas as well as rural areas are placed under pressure and are eventually transformed into cities. Small towns such as Nilai (Negeri Sembilan), Rawang and Dengkil (Selangor) are currently undergoing such changes (Abd Samad, Ahmad Fariz, \& Shaharudin, 2006; Katiman, 2014).

The Malaysian government's initiative in transforming urbanisation is based on four main pillars, namely the 1Malaysia Philosophy, the Government Transformation Programme (GTP), the Economic Transformation Programme (ETP) and the Eleventh Malaysia Plan. The government's transformation step is also being initiated by the implementation of the six National Key Result Areas (NKRAs) aimed at reducing crime, fighting corruption, improving student outcomes, improving rural basic infrastructure and ameliorating urban public transport systems. In order to ensure that the desires and needs of the rural population are fulfilled, the largest allocation has been dedicated to the provision of basic rural infrastructure under the period of three years of NKRA (Ministry of Rural and Regional Development, 2010).

The changes in rural settlement centres in Malaysia are also influenced by the emergence of nearby cities. Factors such as accessibility, environment, safety, activities, neighbourhood and infrastructure have enhanced the existence of the cities (Katiman, 2014). According to Noraniza, Azlizan and Yusuf (2011), infrastructural development has affected changes in small towns as well as neighbourhood and security factors, towards an increase in new and more orderly housing projects (Katiman, Er, Zaini, Abdul Rahim, \& Aishah, 2011). Rural development aims to transform rural areas in order that they can attract investment and become appealing places to live, where residents can enjoy high-quality basic infrastructural facilities and social services (Nurasyikin, 2013). However, according to Haryati and Nurasyikin (2013), development transformation impacts in small towns can 
also lead to decline and negatively affect the well-being of the local community in terms of environmental quality and public health.

This article aims to verify the key factors behind the changes in small towns due to the spillover of the Klang-Langat Valley using Exploration Factor Analysis (EFA) and Confirmatory Factor Analysis (CFA) approaches. Given the continued lack of studies focusing on the factors and impacts of the metropolitan area spillover towards the outer zones of Kuala Lumpur EMR in Malaysia, and especially in the Selangor Northern Corridor which includes small towns such as Batang Kali, Bukit Beruntung, Kalumpang, Kerling, Kuala Kubu Bharu, Rasa, Serendah and Ulu Bernam. This study is considerable pertinence. Population growth, changes in urban functions and roles, the strengthening of economic fundamentals and environmental impacts are among the elements to be studied. The findings in this study may be used as a guide to address the implications of urbanisation in the small towns that are today being affected by globalisation.

\section{SMALL TOWNS AS AGENTS OF SPATIAL TRANSFORMATION}

Classic and modern growth theories emphasise the importance of small towns as being part of a strategy to develop the rural economy. In the 1950s and 1960s, small towns played an important role in development, as centres of innovation and modernisation with the aim of "transferring" the wellbeing generated to rural areas (Tacoli, 2008). At the same time (1960s), various policies were introduced for the development of small towns; however, the majority failed to achieve their goals. Since 2010, most researchers have placed greater emphasis on economic development and poverty eradication programmes (Satterthwaite \& Tacoli, 2003). The best way to develop rural areas is to balance the development of the small town itself. Indeed, the role of small towns in the development of rural areas and peripheral areas is contingent on strategies provided both nationally and globally (Satterthwaite \& Tacoli, 2003).

In general, research and the discourse of small town development are divided into two: first, socioeconomic research and development discussing the role and function of small towns in the context of urban as well as regional development; and second a discourse that views small towns from the perspectives of sociology, ethnology and psychology, such as by studying community layouts, behaviour patterns and social interactions among communities in small towns (Von Bloh, 2008). In particular, small towns are considered centres where all innovation and modernisation is channelled to rural areas, and at the same time interactions between small towns and other peripheral centres will improve. Eventually, the surrounding peripheral areas of the small towns will see development benefits channelled to them. This is the mainstream view and is supported by most researchers such as Hopkins (1979), Tacoli (2004), Wandscheinder (2004) and Satterthwaite (2006).

It is generally acknowledged that small towns in most developing countries should serve as drivers for the emergence of agricultural-based business activities, in addition to providing infrastructure to residents (Katiman, 2007). Small towns also provide institutions for the collection, storage, exchange and distribution of agricultural produce. Moreover, formal and informal education opportunities are also available. Social, cultural and administrative interactions between villagers and 
the bigger cities should also take place. All of these facilities and services form the basis for initiating villages' economic growth, blending innovations and creating job opportunities in distressed areas, especially in developing countries (Katiman, 2007).

These small towns should be easily accessible from anywhere within the hinterland (Rondinelli, 1983). According to Rondinelli (1983), these centres provide goods and services such as education and health to upgrade the living standards of rural communities. If these functions exist, then the roles of a growth centre as a social service provider, development trigger, innovation spreader and job opportunities provider from the non-agricultural sector can be implemented (Satterthwaite \& Tacoli, 2003; Katiman 2007).

According to Hardoy and Satterthwaite (1986), at least five potential factors can explain why governments in developing countries focus on small town development: to constitute the main area for communities and rural enterprises to connect; to form an area with its own political roles; to play a role in achieving national missions; to be a centre of regional development; and to be an agent in controlling the process of urban sprawl. Wandscheinder (2004) also perceives the potential of small towns in assisting local economic development. Based on his findings in several cities such as Betul and Narsimhapur in Madhya Pradesh, as well as Bolangir and Nayarath in Orissa (all in India), he concluded that small towns play an important role in rural development.

In addition, Funnel (1976) explains that small towns represent the place to extract all wealth for the marketing and luxuries of larger cities. He adds that this scenario has occurred as the traditional socioeconomic system has been destroyed by the entry of capitalist economics, especially from European colonial powers that rendered African countries centres for spending the surplus of the rural economy. Currently, economic dominance is held by foreign parties and at the same time economic fundamentals are controlled from London or Paris (Funnel, 1976).

Main city centres are deemed as extracting wealth from rural areas without providing any benefit (returns) to small towns and rural areas. In such instances, small towns may be incapable case of transferring well-being to surrounding areas. However, Funnel (1976) emphasises that there is a strong relationship between the city centre area and peripheral areas through the following three activities:

i. Marketing of social services;

ii. Marketing of consumer goods and services;

iii. Service and agricultural production centre.

In the context of Malaysia, small towns (and especially those located in developed areas) are settlements that can be dynamically influenced by the rapid economic development of nearby developed regions. In this country, a small town is interpreted as a town with a population between 10,000 and 79,999 (Jamaliah, 2004). In 2000, Malaysia had a total of 170 settlements that were considered cities, of which 130 were small towns (Table 1). This is a promising indication, as in 1991 
the number of small towns in Malaysia was only 99 (Jamaliah 2004). What can be summarised is that today's urbanisation process is rapid and stimulating the emergence of many small towns.

Table 1 Small Towns in Malaysia

\begin{tabular}{cccc}
\hline Population Size & Number of Towns & Population ('000) & Distribution (\%) \\
\hline More than 150 000 & 27 & 8959.1 & 65 \\
$75000-149999$ & 13 & 1387.3 & 10 \\
$50000-74999$ & 13 & 775.5 & 6 \\
$25000-49999$ & 34 & 1248.2 & 9 \\
$10000-24999$ & 83 & 1390.2 & 10 \\
\hline Total & 170 & 13760.3 & 100 \\
\hline
\end{tabular}

Source: Jamaliah (2004)

This rapid urbanisation process requires the addition of new areas for the development of residential areas, public facilities, businesses and other urban land uses. Furthermore, the absence of clear urban development limits has resulted in urban sprawl, leading to development being extended to environmentally sensitive areas, major agricultural areas and other areas that are not suitable for development. The control process through the National Physical Plan (NPP) and the implementation of state structure plans and district local plans have yet to show any significant effects.

The National Physical Plan expects that the urbanisation rate in Malaysia will increase to 75 percent by the year 2020 (National Physical Planning Council, 2005). This scenario will be followed by the process of population growth, which is mostly concentrated in major conurbations such as Kuala Lumpur, George Town, Johor Bahru and Kuantan. However, the function and role of small towns in the urbanisation process should not be taken lightly: small towns such as Nilai, Rawang, Dengkil, Balakong and Ulu Tiram have all experienced drastic changes over the past 20 years (National Physical Planning Council, 2005; Katiman 2007). Furthermore, globalisation brings development from central areas to peripheral areas, rendering the functions and roles of small towns today very different from in the past.

In addition, Katiman (2005) proves that the influence of globalisation has a major impact on the urbanisation process in Malaysia, especially in the Klang Valley area. The influx of foreign capital through multinational companies has caused rapid urbanisation. Although urban boundaries remain unchanged, certain urban implications and influences continue to occur and become exacerbated in peripheral areas. For example, the Klang-Langat Metropolitan Region spillover can now be observed as spreading as far as Hulu Selangor and Kuala Langat. At the same time, the rapid urbanisation process due to the influence of globalisation has changed the functions and roles of cities that were once small towns. Indeed, cities such as Nilai (Negeri Sembilan), Balakong, Kajang, Hulu Langat, Dengkil and Banting (Selangor), as well as Senai and Ulu Tiram (Johor), have experienced or are experiencing a relatively rapid process of transformation (National Physical Planning Council, 2005; Abdul Samad et al., 2006; Katiman 2007). 
This scenario clearly demonstrates that in this era of globalisation, urbanisation is not only concentrated on big cities, but is also spreading to small towns. Therefore, the factors, influences, roles and contributions of small towns to the development of the country should not be underestimated. This is due to the fact that these small towns form the backbone of support for bigger cities through the urban-village interaction process. In addition, the role of small towns also helps in the process of regional development, whether locally or globally.

\section{METHODOLOGY}

This study is a survey study using a questionnaire method to obtain data. The study involved 355 respondents selected by simple random sampling and consisting of heads of household the study area. A five-point scale questionnaire instrument was used to obtain feedback.

\section{Instrument}

The instrument used in this study was a questionnaire measuring the change factors of small towns along the Selangor Northern Corridor resulting from the spillover of the Klang-Langat Valley Metropolitan Region. The study sample consisted of 355 heads of household residing in the Hulu Selangor area and selected by stratified random sampling. The construction of questionnaire items was based on items identified from a previous study. This study employed six constructs, namely Neighbourhood, Accessibility, Environment, Safety and Infrastructure Activities. All items underwent Exploratory Factor Analysis and Confirmatory Factor Analysis. Items were measured on a 5-point Likert scale (1-Strongly Disagree, 2-Disagree, 3-Somewhat Disagree, 4-Agree and 5-Strongly Agree). The number of items and question of each item are summarised in Table 2.

Table 2 Items and Question Items of the Questionnaire

\begin{tabular}{cl}
\hline Item & Question Item \\
\hline J1 & Satisfied with the neighbourhood setting \\
J2 & Family relationship with neighbourhood spirit \\
J3 & Neighbourhood relationship with clannish groups \\
& Family relationship as opposed to neighbourhood \\
J4 & relationship \\
J5 & The importance of relationship with neighbours \\
J6 & The closeness of relationship with neighbours \\
J7 & Visiting each other within the neighbourhood \\
J8 & Participation in community's activities in your area \\
J9 & The residential place is safe to live in \\
J10 & Promiscuity \\
J11 & Immigrants \\
J12 & Motorcycle, car, property theft \\
J13 & Armed home robbery \\
J14 & Blackmailing \\
J15 & Rempit and drug abuse
\end{tabular}




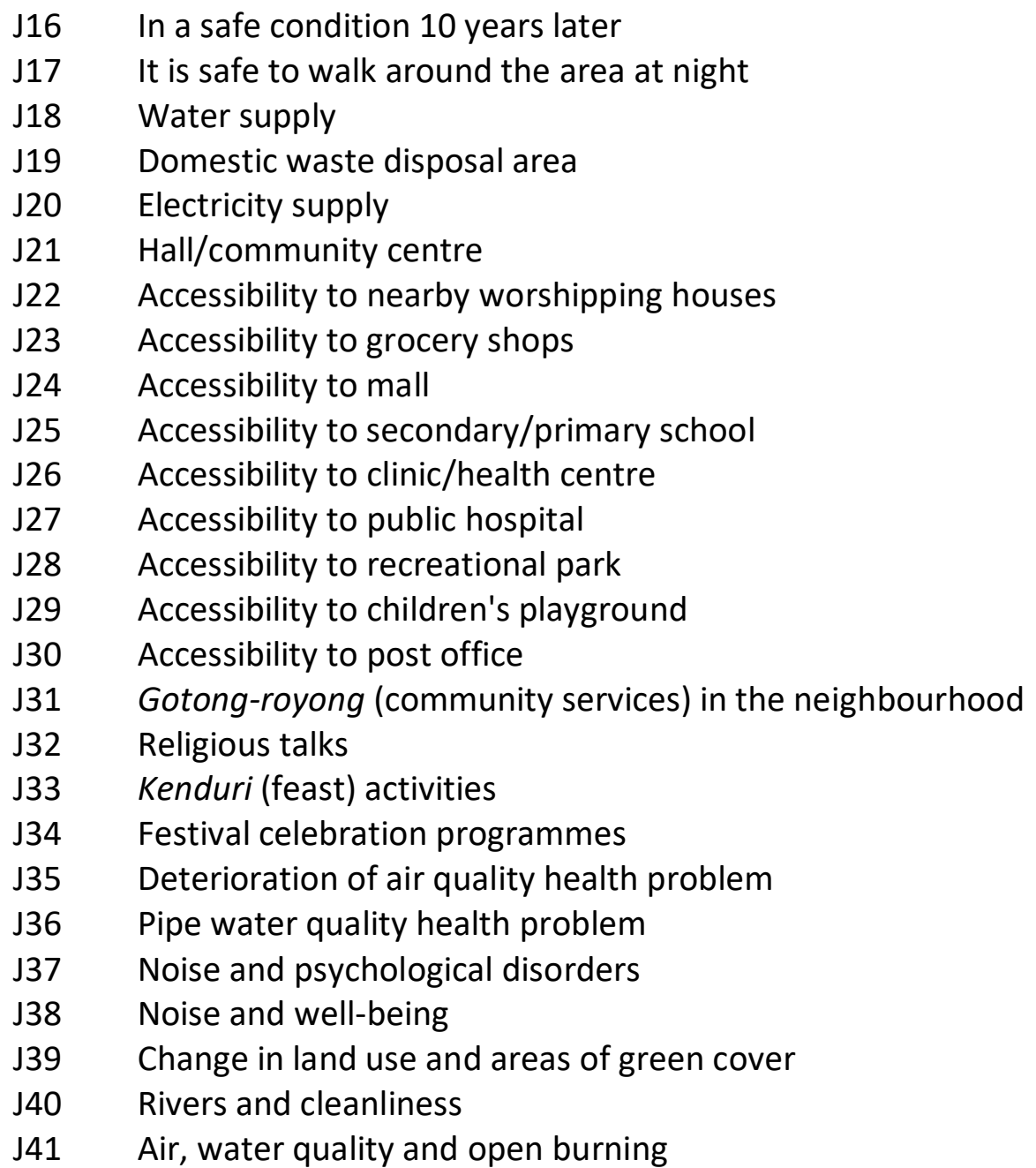

\section{Data Analysis Methods}

The data used in this study were analysed using SPSS version 22.0 and AMOS version 22.0. Data analysis involved three stages. The first stage was reliability analysis with each construct to ascertain the reliability level of the data obtained. The second analysis focused on the demographic information of the respondents involved in this study, which was analysed descriptively. This was important in order to note the frequency and percentage of each respondent's demographic factors (Zainol, Wong \& Mohd Rashid, 2013). Next, the third analysis comprised exploratory factor analysis on the study items to recognise how they were classified according to the structure of certain factors (Hair, Anderson, Tatham, \& Black, 2010). The next step was to confirm the hypothesis model by the Structural Equation Modelling (SEM) method through Confirmatory Factor Analysis (CFA). 


\section{Reliability Analysis}

In general, a reliability test is important as a means of measuring the capability of the items in the instrument used. Reliability is the accuracy and stability of the points or marks of the measurement scale (Hair et al., 2010). According to Sekaran and Bougie (2009), the higher the alpha value, the higher the internal reliability. This study set the 0.70 value of Alpha Cronbach coefficient to be accepted as suggested by Pallant (2010), Babbie (2007) and Hair, Black, Babin and Anderson (2006). By referring to the analysis results in Table 3, the reliability of all items in this instrument exceeded 0.7. This indicated that the reliability of the items constructed as part of the questionnaire was acceptable.

Table 3 Reliability Values of the Study's Questionnaire

\begin{tabular}{llcc}
\hline \multicolumn{1}{c}{ Part } & \multicolumn{1}{c}{ Construct } & $\begin{array}{c}\text { No. of } \\
\text { Items }\end{array}$ & $\begin{array}{c}\text { Alpha Cronbach } \\
\text { Value }\end{array}$ \\
\hline \multirow{3}{*}{ Factor of the change in } & Accessibility & 5 & 0.846 \\
small towns & Environment & 5 & 0.871 \\
& Safety & 2 & 0.819 \\
& Activity & 4 & 0.883 \\
& Neighbourhood & 2 & 0.729 \\
& Infrastructure & 2 & 0.766 \\
\hline
\end{tabular}

\section{Factor Analysis}

Factor analysis is a statistical approach used to analyse the relationship between several constructs and to explain the constructs in the form of certain latent factors (Hair et al., 2010, Chua, 2009). It is a statistical approach that is used to summarise the information contained in several original constructs to a smaller or general dimension. The approaches of factor analysis can be grouped into two fundamentally different approaches, namely exploratory factor analysis and confirmatory factor analysis.

\section{a. Exploratory Factor Analysis (EFA)}

Exploratory factor analysis can be described as an order to summarise related constructs. It is a construct reduction technique that shows the number of latent constructs and the underlying factor structure of a set of constructs (Hair et al., 2010; Chua, 2009). According to Chua (2009), EFA is used to explore the factor structure that may underlie a set of constructs being studied without imposing the structure formed before conducting further analysis. Through this EFA, the number of constructs and the factor structure underlying the constructs studied can be identified. The factor structure formed is based on the feedback results of the study sample.

\section{b. Confirmatory Factor Analysis (CFA)}

Confirmatory factor analysis is a statistical technique that is used to confirm the factor structure of a set of constructs studied (Byrne, 2010; Hair et al., 2010). Confirmatory factor analysis 
allows researchers to test the hypothesis whether the relationship between the constructs examined and the factor loading exists or not (Byrne, 2010; Hair et al., 2010). Researchers use theoretical knowledge, empirical research or both to obtain a preferred correlation pattern, and the hypothesis is subsequently tested using statistical methods (Byrne, 2010; Hair et al. 2010).

\section{RESULTS AND DISCUSSION}

\section{Respondents' background}

Most (54.6 per cent, 194 respondents) of the heads of household who participated in the census in Hulu Selangor were Malays. Chinese and Indians comprised about 25.4 per cent (90 heads of household) and 20.0 per cent (71 heads of household), respectively. Malays formed the ethnic majority in the Hulu Selangor district. This was proven by analyses carried out on statistical data published based on population and housing census reports since the 1980s. The number of ethnic Malays in the Hulu Selangor district based on the population and housing census report in 2010 was found to be 127,783 people, compared to ethnic Chinese at 23,176 . The population proportion of ethnic Indians is 31,580 people, making them the second largest ethnic group in Hulu Selangor.

In terms of the age structure of the heads of household, two groups can be identified: the group of active workforce between the ages of 25 and 54, and the group of elders over 60 years old. The largest number of heads of household comprised those who are active in various employment sectors, at 64.1 per cent ( 228 heads of household). Unemployed heads of household or retirees are represented by 26.3 per cent (127 persons) of the total heads of household under study.

The economic status of the heads of household involved in the survey varied. In terms of average monthly income, the majority can be classified in the medium category. Indeed, 31.2 per cent or 109 heads of household earn an average income of around RM2,000 to RM2,999, while 30.2 per cent can be considered low income, earning around RM900 to RM1,999 per month. This shows that the population of the sub-district (mukim) in this study area is not particularly poor. Most of the population in the sub-districts in the study area work as part of the semi-skilled employment sector, which does not require special expertise. They are also assumed to be among the non-professional middle-income groups on a monthly basis. Only a small proportion (14.0 per cent, 49 heads of household) can be categorised as high-income, with monthly earnings exceeding RM4,000 per month.

\section{Exploratory Factor Analysis (EFA)}

The results of EFA Analysis on the measuring instrument of the change in small towns along the Selangor Northern Corridor due to the spillover of the Klang-Langat Valley Metropolitan Region explained that the anti-image correlation analysis procedure showed that the correlation coefficient value exceeded 0.5. The sampling adequacy measurement of Kaiser-Meyer-Olkin (KMO) and Bartlett's Test of Sphericity obtained indicated that the KMO value was 0.759 , with the latter significant with a Chi-square value of 6821.722 at a degree of freedom of 820. 
Table 4 Kaiser-Meyer-Olkin (KMO) and Bartlett's Test

\begin{tabular}{lll}
\hline $\begin{array}{l}\text { Measure of sampling } \\
\text { adequacy for KMO }\end{array}$ & 0.759 \\
\hline Barlett's Test & Chi-square Value & 6821.722 \\
& Degree of Freedom & 820 \\
& Significance & .000 \\
\hline
\end{tabular}

A factor analysis was conducted in which the researchers determined a number of factors to be extracted into six, as categorised in the questionnaire. Table 5 displays the component matrix with varimax rotation. The varimax rotation method was performed as it reduces the amount of complex constructs and increases the expected yield. From the results, it was found that the items with an anti-image correlation matrix value of less than 0.5 had been dropped. The values of J29, J25, J27, $\mathrm{J} 30, \mathrm{~J} 26, \mathrm{~J} 24, \mathrm{~J} 28, \mathrm{~J} 23$ and $\mathrm{J} 22$ are included in component 1 , which is accessibility, while J37, J36, J38, J35, J39 and J41 are accumulated in component 2, which is environment. Next are J12, J13, J10, J15, $\mathrm{J} 11$ and $\mathrm{J} 14$, assembled in component 3 , which is security, and J33, J34, J32 and J31 are in group 4, which is community activity. As for component 5, which is neighbourhood, the items collected comprise J8, J6, J7, J9, J1 and J5. As for the last component, which is infrastructure, the accumulated items are J20, J18, J19 and J21. The values shown in Table 5 are the coefficients or factor loadings for each item that tend to each factor being accumulated. These values show the correlation between the items and the factors conceived, and this is the key to understanding the nature of these factors. Next, a CFA analysis was conducted to confirm the results obtained from the EFA analysis. 
Table 5 The Component Matrix with Varimax Rotation for the Construct of the Factors of Change in Small towns along the Selangor Northern Corridor due to Spillover of the Klang-Langat Valley Metropolitan Region

\begin{tabular}{|c|c|c|c|c|c|c|}
\hline \multirow{2}{*}{ Item } & \multicolumn{6}{|c|}{ Component } \\
\hline & Accessibility & Environment & Safety & Activity & Neighbourhood & Infrastructure \\
\hline$J 29$ & .764 & & & & & \\
\hline $\mathbf{J} 25$ & .730 & & & & & \\
\hline$J 27$ & .711 & & & & & \\
\hline J30 & .694 & & & & & \\
\hline$J 26$ & .670 & & & & & \\
\hline$J 24$ & .667 & & & & & \\
\hline$J 28$ & .657 & & & & & \\
\hline$J 23$ & .601 & & & & & \\
\hline$J 22$ & .522 & & & & & \\
\hline J37 & & .858 & & & & \\
\hline J36 & & .828 & & & & \\
\hline J38 & & .803 & & & & \\
\hline J35 & & .753 & & & & \\
\hline J39 & & .734 & & & & \\
\hline $\mathrm{J} 41$ & & .595 & & & & \\
\hline J12 & & & .708 & & & \\
\hline J13 & & & .662 & & & \\
\hline $\mathrm{J} 10$ & & & .651 & & & \\
\hline $\mathrm{J} 15$ & & & .647 & & & \\
\hline $\mathrm{J} 11$ & & & .627 & & & \\
\hline $\mathrm{J} 14$ & & & .586 & & & \\
\hline J33 & & & & & & \\
\hline J34 & & & & & & \\
\hline $\mathrm{J} 32$ & & & & & & \\
\hline J31 & & & & & & \\
\hline $\mathrm{J} 8$ & & & & & .707 & \\
\hline $\mathrm{J} 6$ & & & & & .661 & \\
\hline J7 & & & & & 649 & \\
\hline J9 & & & & & .574 & \\
\hline $\mathrm{J} 1$ & & & & & .552 & \\
\hline $\mathrm{J} 5$ & & & & & .525 & \\
\hline $\mathrm{J} 20$ & & & & & & .780 \\
\hline $\mathrm{J} 18$ & & & & & & .730 \\
\hline J19 & & & & & & .719 \\
\hline $\mathrm{J} 21$ & & & & & & .591 \\
\hline
\end{tabular}

- Legend : the darkened items are items that are not dropped

\section{Confirmatory Factor Analysis (CFA)}

According to Hair et al. (2010), a model is said to be suitable if it meets at least one matching index. Moreover, in order to measure the suitability of a model, statistical measurements such as relative chi-square test, Comparative Fit Index (CFI) and Root Mean Square of Error Approximation (RMSEA) should be used (Hair et al. 2010). In order to achieve a model's suitability, the value of relative chi- 
square must be less than 5.0, while the CFI and TLI values must exceed 0.90. As for RMSEA, the value should be less than 0.08 for data to be adopted (Schumacker and Lomax, 2004).
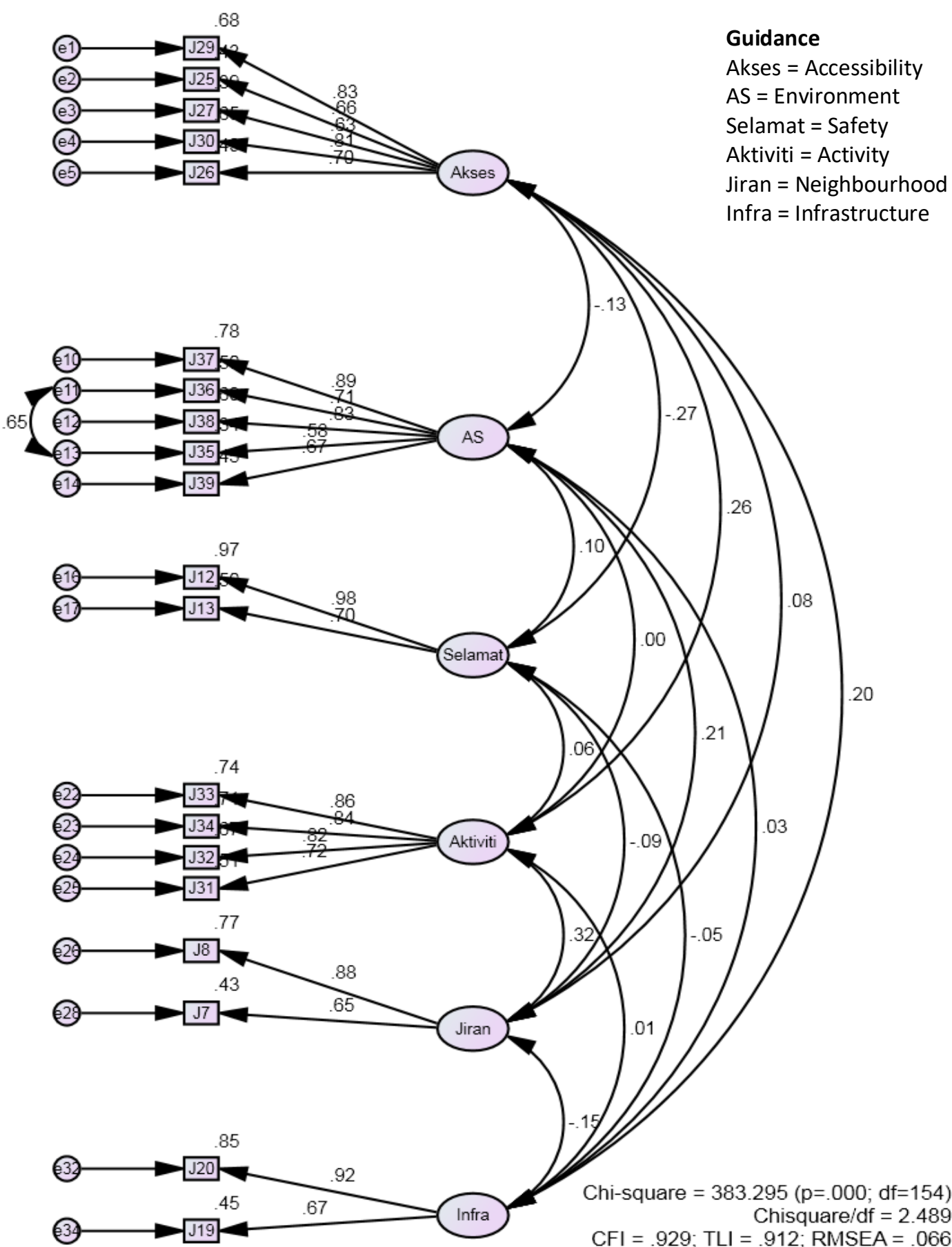

Figure 1 Confirmatory Factor Analysis Model (CFA) for the Change in Small towns along the Selangor Northern Corridor due to the Klang-Langat Valley Metropolitan Region Spillover. 
Figure 1 of CFA analysis shows the factor model of the change in small towns along the Selangor Northern Corridor as a result of the spillover of the Klang-Langat Valley Metropolitan Region, which reflects a suitable model based on the corresponding index. The findings show that the corresponding index value is equal to $p=0.000$, the relative chi-square value is equal to 2.489 , a CFI value of 0.929 , 0.912 for TLI, and an RMSEA value that equals 0.066 . The evaluation of squared multiple correlation (SMC) also found that all values exceeded 0.50 . This means that more than 50 per cent of the variance of each item can explain the construct.

In addition, all of the six constructs were correlated with one another (Table 6). This shows that accessibility, environment, security, activity, neighbourhood and infrastructure are the change factors of the small towns along the Selangor Northern Corridor due to the spillover of the KlangLangat Valley Metropolitan Region, as stated by Katiman (2014) as well as by Noraniza, Azlizan and Yusuf (2011). The outcomes of rural development transformation have rendered rural areas more attractive for investment, and residents and communities in this area are able to enjoy all of the same basic facilities of infrastructure and high-quality social services as counterparts in the city (Nurasyikin, 2013; Katiman, Er, Zaini, Abdul Rahim \& Aishah, 2011).

Table 6 Correlation between All Six Constructs

\begin{tabular}{cccccc}
\hline Constructs & Accessibility & Environment & Safety & Activity & Neighbourhood \\
\hline Environment & -.132 & & & & \\
Safety & -.268 & .095 & & & \\
Activity & .261 & .004 & .060 & & \\
Neighbourhood & .079 & .212 & -.086 & .318 & \\
Infrastructure & .195 & .032 & -.054 & .012 & -.153 \\
\hline
\end{tabular}

\section{CONCLUSION}

The small towns along the Selangor northern corridor have undergone rapid changes following the transformation that has taken place. These chenges affects the physical environment and the wellbeing of the population. As explained in the beginning of this article, this article aims to verify the key factors behind the changes in small towns due to the spillover of the Klang-Langat Valley using Exploration Factor Analysis (EFA) and Confirmatory Factor Analysis (CFA) approaches. Based on the findings, this study concludes that there are six key factors behind the changes in small towns in Selangor Northern Corridor due to the spillover of the Klang-Langat Valley namely accessibility, environment, safety, activity, neighbourhood and infrastructure.

All of these factors play an important role in bringing changes to existing small towns. Changes resulting from these factors can can effects on the physical of the small town and socio-economic of their population. For future studies, factors that have been identified in this study can be used in the 
study particularly in analyzing the well-being of population population and also in identifying sustainability of a small town.

\section{REFERENCES}

Abdul Samad, H., Abdul Hadi, H. S., Ahmad Fariz, M. \& Shaharudin Idrus. (2006). Mencari kelestarian bandar kecil. Bangi: Penerbit Universiti Kebangsaaan Malaysia.

Babbie, E. (2007). The practice of social research. Belmont, California: Thomsom Wadsworth.

Byrne, D. \& Baron, R. A. (1997). Social psychology (8th ed.). Boston, MA: Allyn \& Bacon, Inc.

Chua, Y. P. (2009). Statistik penyelidikan lanjutan ujian regresi, analisis factor dan analisis SEM. Kuala Lumpur: McGraw-Hill (Malaysia) Sdn. Bhd.

Funnell, D. C. (1976). The role of small town in regional and rural development: With special reference to Eastern Africa. Dalam Gilbert A (eds) Development planning and spatial structure. John Wiley \& Sons, Bath.

Hair, J. F., Anderson, R. E., Tatham, R. L., \& Black, W. C. (2010). Multivariate data analysis (4 ${ }^{\text {th }}$ ed.). New Jersey: Prentice Hall.

Hardoy, J. E. \& Satterthwaite, D. (1986). The nature of housing need among lower income groups, section of article Shelter, infrastructure and services in third cities. Habitat International, 10(3), 247-250.

Haryati, S. \& Nurasyikin, M. (2013). Transformasi dan pembangunan luar bandar: kesan ke atas penduduk dan persekitaran. International Journal of the Malay World and Civilisation, 1(2), 71-81.

Hopkins NS (1979) The small town in urban development: Kita (Mali) and Testour (Tunisia). Africa, 49(3), 316-328.

Jamaliah, J. (2004). Emerging trends of urbanisation in Malaysia Statistics Malaysia. Journal of the Department of Statistics Malaysia, 1, 43-54.

Katiman, R. (2005). Transformasi ekonomi dan perbandaran di Koridor Kemaman-Dungun, Terengganu: Kerterlibatan isi rumah melayu. Sari, 23, 15-36

Katiman, R. (2014). Kerja lapangan dalam aspek transformasi desa-bandar dan pembandaran. Dalam Kerja Lapangan: Teknik, Prosedur dan Aplikasi dalam Geografi. Wan Ruslan Ismail, Narimah Samat, \& Nooriah Yusof. (Penyt.) Pulau Pinang: Penerbit Universiti Sains Malaysia.

Katiman, R., Er, A. C., Zaini, S., Abdul Rahim, M. N. \& Aishah, M. (2011). Pembandaran di Pinggir Wilayah Metropolitan Lanjutan: Beberapa Implikasi terhadap Corak dan Kualiti Kejiranan. Akademika, 81(3), 19-29.

Katiman, R. (2007). Transformasi desa-bandar di pinggiran Wilayah Metropolitan: Beberapa bukti di sekitar Dengkil, Malaysia. Seminar BKPPM. Universiti Sains Malaysia, 17-18 Januari 2007, Sandy Beach Resort, Pulau Pinang.

Kementerian Kemajuan Luar Bandar dan Wilayah. (2010). Pelan induk pembangunan luar bandar. Putrajaya: Kementerian Kemajuan Luar Bandar dan Wilayah.

Majlis Perancang Fizikal Negara. (2005). Rancangan Fizikal Negara (RFN). Putrajaya: Majlis Perancang Fizikal Negara.

Noraniza, Y., Azlizan, T. \& Yusuf, P. (2011). Impak Pembangunan Infrastruktur ke atas Pembangunan Komuniti Penduduk di Daerah Pendang dan Kubang Pasu, Kedah Darul Aman, Malaysia. JGD Journal of Governance and Development, 16(7), 16-36. 
Nurasyikin, M. (2013). Transformasi Pekan Parit Raja: Kajian terhadap kesejahteraan hidup masyarakat. (Tesis Sarjana). Fakulti Pengurusan Teknologi dan Perniagaan, Universiti Tun Hussein Onn Malaysia.

Pallant, J. (2010). SPSS survival manual: A step by step guide to data analysis using SPSS (4th ed.). Maidenhead: Open University Press/McGraw-Hil.

Rondinelli, D. A. (1983) Bandar sekunder di negara membangun: Ke arah dasar pembangunan tersebar (terjemahan). Dewan Bahasa dan Pustaka, Kuala Lumpur.

Saleh, Y., Hashim, M., Mahat, H., \& Nayan, N. (2017). Issues of Rural-Urban Transformation on the Fringe of Metropolitan Region: Several Findings from the Selangor Northern Corridor, Malaysia. International Journal of Academic Research in Business and Social Sciences, 7(6), 913924.

Satterthwaite, D. \& Tacoli, C. (2003). The urban part of rural development: the role of small and intermediate urban centres in rural and regional development and poverty reduction. IIED, London. Diperoleh daripada http://pubs.iied.org/9226IIED/.

Satterthwaite, D. (2006). Outside the large cities the demographic importance of small towns and large villages in Africa, Asia and Latin America. Obtained from http://www.iied.org/pubs/display.php?o=10537IIED.

Sekaran, U., \& Bougie, R. (2009). Research methods for business: A skill building approach (5th Ed.). United Kingdom: John Wiley \& Sons.

Tacoli, C. (2004). Rural-urban linkages and pro-poor agricultural growth: An overview. OECD DAC POVNET, Agriculture and Pro Poor Growth Task Team, Helsinki Workshop, 17-18 June. Diperoleh daripada http://www.oecd.org/development/povertyreduction /36562896.pdf.

Tacoli, C. (2008). Links between rural and urban development in Africa and Asia. London: International Institute for Environment and Development.

Von Bloh, H. (2008). Small towns as interfaces for interaction, exchange and transition in Vietnam. The Austrian Journal of South East Asian Studies (ASEAS), 1 (2), 7-18.

Wandschneider, T. (2004) Small rural towns and local economic development: Evidence from two poorest states in India. International Conference on Local Development, Washington, 17-18 June 2004. Diperoleh daripada http://www.dfid.gov.uk/r4d/PDF/Outputs/

EcoDev/wandschneider_2004_icld.pdf.

Zainol, M., Wong, W. L., \& Mohd Rashid, A. H. (2013). Persepsi pelajar terhadap hasil pembelajaran bidang kejuruteraan. Jurnal Teknologi, 62(1), 41-48.

\section{ACKNOWLEDGEMENT}

The discussion in this article forms part of the findings of an investigation entitled 'The Development of the Indicators for Rural Urban Transformation at the Peri Urban Areas of Klang-Langat Valley Extended Metropolitan Region' sponsored by the Ministry of Higher Education Top-Down Grant 2016 (2016-0238-106-41). 